\title{
Advanced Hardwood Biofuels Northwest: Commercialization Challenges for the Renewable Aviation Fuel Industry
}

\author{
Brian J. Stanton ${ }^{1, *}$ and Richard R. Gustafson ${ }^{2}$ \\ 1 Biological Research Group, GreenWood Resources, 1500 S. W. First Avenue Portland, OR 97201, USA \\ 2 School of Environmental and Forest Resources, University of Washington, Box 352100, \\ Seattle, WA 98195, USA; pulp@u.washington.edu \\ * Correspondence: brian.stanton@gwrglobal.com
}

Received: 27 August 2019; Accepted: 25 October 2019; Published: 1 November 2019

\begin{abstract}
A bioenergy summit was organized by Advanced Hardwood Biofuels Northwest (AHB) to debate the barriers to the commercialization of a hybrid poplar biofuels industry for the alternative jet fuels market from the perspective of five years of AHB research and development and two recent surveys of the North American cellulosic biofuels industry. The summit showed that: (1) Growing and converting poplar feedstock to aviation fuels is technically sound, (2) an adequate land base encompassing 6.03 and 12.86 million respective hectares of croplands and rangelands is potentially available for poplar feedstock production, (3) biofuel production is accompanied by a global warming potential that meets the threshold $60 \%$ reduction mandated for advanced renewable fuels but (4) the main obstruction to achieving a workable poplar aviation fuels market is making the price competitive with conventional jet fuels. Returns on investment into biomass farms and biorefineries are therefore insufficient to attract private-sector capital the fact notwithstanding that the demand for a reliable and sustainable supply of environmentally well-graded biofuels for civilian and military aviation is clear. Eleven key findings and recommendations are presented as a guide to a strategic plan for a renewed pathway to poplar alternative jet fuels production based upon co-products, refinery co-location with existing industries, monetization of ecosystem services, public-private financing, and researching more efficient and lower-costs conversion methods such as consolidated bioprocessing.
\end{abstract}

Keywords: advanced hardwood biofuels; renewable aviation fuels; hybrid poplar; feedstock conversion; biochemical fuels platform

\section{Introduction}

GreenWood Resources and the University of Washington convened a bioenergy summit under the auspices of Advanced Hardwood Biofuels, Northwest (AHB; http://hardwoodbiofuels.org/) in Portland, Oregon on 10 August 2017. The summit brought together bioenergy stakeholders to discuss what needs to transpire before hybrid poplar biofuels becomes a realistic investment opportunity. The summit included participants from industry, academia, government agencies, state and federal legislators, the U.S. National Laboratories, the Native American community and the non-profit environmental sector. Initial deliberations were structured as three breakout sessions on the economics and sustainability of the hybrid poplar biofuels production system. These were followed by a plenary session in which recommendations from the breakouts were presented and discussed. This paper reviews the literature on the strategic aspects of the hybrid poplar-to-biofuels industry and documents the main technical, regulatory, and market challenges raised during the summit, and makes recommendations for commercialization. 
AHB is a consortium of universities and industries funded under the USDA-NIFA's 2011 Agriculture and Food Research Initiative, "Regional Approaches to Sustainable Bioenergy." AHB's purpose is to lay a foundation for the Pacific Northwest biofuels and bioproducts industry using sustainably managed hybrid poplar biomass farms. The summit was conceived as an AHB commercialization effort with the intent of facilitating cooperation among the federal government, industry, non-governmental agencies, and academia as described in the National Science and Technology Council's Federal Alternative Jet Fuels Research and Development Strategy [1]. The University of Washington is AHB's principal investigating organization and directs the work of its academic partners (Oregon State University, University of Idaho, University of California, Davis, Portland State University, Washington State University, The Agricultural Center of Excellence at Walla Walla Community College) and industry members (GreenWood Resources, Rocky Mountain Wildlife Institute, Zeachem, New Holland Agriculture). The University of Washington leads the work in biomass conversion based on Zeachem's biochemical process of biomass fractionation, carbohydrate recovery and hydrolysis, fermentation to acetic acid, reduction to ethanol, and conversion to drop-in jet fuel. The University of Washington also conducts life cycle analyses, and the University of California, Davis models the sustainability of the entire hybrid poplar biomass enterprise. GreenWood Resources manages four biomass demonstration farms and directs field trials in feedstock production practices. AHB has concluded that the agronomy, biochemistry, and sustainability of the hybrid poplar biofuels system has outstanding potential but faces substantial near-term barriers to commercialization under the current petroleum market conditions [2].

\section{Background}

Two papers, the first published at the outset of the cellulosic biofuels movement in 2006 [3], and the second published in 2017 [4] as an accounting of the project's progress and outlook, together provide context for the summit's deliberations. In 2006, the technology of producing renewable transportation fuels was coming to fruition with the expectation that the industry as articulated by President Bush's Biofuels Initiative, the Energy Policy Act of 2005, would soon be competitive in price and performance with petroleum fuels by 2012. (This legislation mandated levels of biofuels production that were project to grow to an annual amount of 136 billion liters by 2022. The act also authorized $\$ 50$ million annually for biomass grants.) Ethanol was touted as the preferred biofuel as it could be used directly as an additive to conventional fuels. Support was "at an all-time high" among the oil, chemical, and automotive industries [3], notwithstanding several critical unknowns: (1) The energy balance in producing biofuels, (2) future implementation of blending mandates, (3) the cyclicality in crude oil prices, and (4) projections around future oil supplies. Regarding the latter unknown, it is noteworthy that the 2006 assessment did not anticipate hydraulic fracking technology, stating that, "Nor does it seem likely that new technologies will enable oil to be recovered from sources that are currently economically inaccessible." Proponents of renewable energy envisioned the cellulosic biofuel business to be established by 2015 with the support of the 2005 Energy Policy Act's biofuels program, and federal funding of a coordinated advanced biofuels agenda. To solidify the industry's growth, certain milestones were advised such as moving from batch fermentation to continuous flow or consolidated bioprocessing to improve economic performance [3]. Biotechnology was enlisted to strengthen the industry by solving two critical challenges: (1) The cost-effective liberation of sugars from biomass and (2) agronomic systems capable of sizable amounts of biomass in an environmentally and economically sustainable way [5].

But as fracking unlocked new oil and gas reserves and U.S. oil output was projected to reach 10 million barrels a day by 2018, breaking the record set in 1970, realization of the cellulosic biofuels market was slower and costlier [6]. In short, the petroleum industry's expanded capacity that considerably increased the supply of crude oil with a corresponding reduction in prices, posed a complicated challenge for biofuels [7]. By 2016, prices for crude oil had dropped precipitously to between $\$ 40$ and $\$ 50$ a barrel, far below 2008's pre-collapse high of $\$ 147$ a barrel. It was reported that 
Shell Oil was bracing for a world where oil prices might stay "forever low" because of the U.S. shale revolution and the resulting glut in fossil fuel [8]. By 2011, the enormity of the economic challenge in converting lignocellulosic feedstock into ethanol was being fully appreciated [9].

But the fate of the cellulosic industry turned on more factors than the new fossil fuel extraction technology. Premature endorsement of cellulosic conversion technology, the promotion of large biorefineries, a lack of sustained support from government funding agencies, and policies designed for commercialization as opposed to development were all weighty drags on the industry's growth [4]. Unfortunately, the cellulosic industry could not pursue the methodical, incremental approach to commercialization that had worked well in building the solar and wind industries [4] primarily because of the large economies of scale in building a biorefinery [10].

Looking forward, ethanol remains positioned as the renewable fuel of choice, because of its good conversion yield, relative ease of production, and the potential for high-value chemical co-products. Life cycle analyses of ethanol production from hybrid poplar estimate a reduction in global warming potential of $51 \%$ for E85 blends and $62 \%$ for E100 fuels [11]. Furthermore, AHB has found that cellulosic ethanol could achieve carbon neutrality depending on the process details [12]. Long term, however, as electric cars become more common, renewable hydrocarbon fuels will move to a dominant position servicing those sectors-aviation, long-haul trucking, and marine shipping-that are challenging to power with batteries or ethanol [13].

But as of 2017, Ethanol Producer Magazine reported that while commercial-scale, cellulosic ethanol plants had completed construction and were in the final stages of commissioning, none had produced fuels in commercial quantities [14]. Since the magazine's assessment, several refineries have curtailed production or shut down. Accordingly, four propositions have been brought forward to revitalize the business of cellulosic biofuels: (1) Promotion of biofuel's social and environmental attributes, (2) investment in more-cost effective conversion technologies, (3) initiation of the industry using feedstocks with established supply chains, and (4) progression from research and demonstration to commercialization in a step-wise manner [15]. Along the lines of the first three of these propositions, it is widely acknowledged that hybrid poplar has much to offer. First, the environmental impact of poplar biomass production should be an improvement over the first-generation energy crops and second-generation herbaceous perennial ones especially as coppice cycles are lengthened [15-17]. Reductions in greenhouse gas emissions from hybrid poplar relative to perennial herbaceous biomass crops have been reported to be improved by $26 \%$ to $38 \%[15,18]$ and roughly equivalent to those of successional herbaceous plants on marginal lands [19]. Related is the projected annual value of environmental benefits owing from cropland conversion to hybrid poplar biomass production (water quality enhancement and carbon sequestration) that has been estimated between $\$ 6$ and $\$ 50 \mathrm{ha}^{-1}$ [20]. Second is the long history of research and development of hybrid poplar specifically as a biomass species beginning with the U.S. Department of Energy's Short Rotation Woody Crops Program that began, in 1990, with yield projections of $9.0 \mathrm{Mg} \mathrm{ha}^{-1} \mathrm{yr}^{-1}$ to $16 \mathrm{Mg} \mathrm{ha}^{-1} \mathrm{yr}^{-1}$ following a successive six-year rotations and delivered cost of $\$ 40 \mathrm{Mg}^{-1}$ to $\$ 105 \mathrm{Mg}^{-1}$ [21,22]. More recently, yields up to $20 \mathrm{Mg} \mathrm{ha}^{-1} \mathrm{yr}^{-1}$ over four consecutive three-year coppice rotations have been measured [23]. Today, research in feedstock genomics and conversion technology at the Department of Energy's Center for Bioenergy Innovation (CBI) features hybrid poplar as one of the project's main feedstocks. Third, hybrid poplar is differentiated among all other purpose-grown, cellulosic feedstock candidates as the only one with a history of commercial use and a proven supply chain. The past reliance on hybrid poplar by the pulp and paper and veneer industries will accelerate the design of similarly efficient logistics for the biorefining industry, encompassing local sourcing and satellite preprocessing [24].

\section{AHB Research and Development, 2012-2017}

The AHB research and development program was organized within three domains: (1) Feedstock production through growth, harvest, and delivery of biomass; (2) biomass conversion to liquid fuels; and (3) environmental and economic sustainability of the production and conversion system. 
Feedstock Production-Under AHB, GreenWood Resources managed large-scale hybrid poplar farms in Idaho, Oregon, California, and Washington to demonstrate biomass yields, production costs, and harvesting technology in growing renewable feedstock. The yield of the top-performing hybrid varieties during the three-year coppice production cycle at the Idaho farm was 15.7 dry metric tons per hectare per year $\left(\mathrm{Mg} \mathrm{ha}^{-1} \mathrm{yr}^{-1}\right), 18.1 \mathrm{Mg} \mathrm{ha}^{-1} \mathrm{yr}^{-1}$ at the Oregon farm, $12.9 \mathrm{Mg} \mathrm{ha}^{-1} \mathrm{yr}^{-1}$ in California, and $22.2 \mathrm{Mg} \mathrm{ha}^{-1} \mathrm{yr}^{-1}$ in Washington. The cost of land, labor, fuel, and equipment involved in growing, harvesting, and transporting poplar feedstock to refineries within a $65-\mathrm{km}$ radius were compiled and described in a biomass production cost calculator for each of the four regions assuming leased land and yields of the top-performing varieties [25]. The breakeven price for delivered biomass ranged from $\$ 66.64 \mathrm{Mg}^{-1}$ (Washington) to $\$ 152.49 \mathrm{Mg}^{-1}$ (California). GreenWood also studied the sensitivity of internal rates of investment return to key variables using a discounted cash flow analysis [26]. Returns were found to be most sensitive to assumptions related to biomass prices, yields, and land costs. Farm investment returns averaged $4 \%$ in real, inflation-adjusted terms across all sites with an assumed market biomass price of $\$ 100 \mathrm{Mg}^{-1}$; this result is unlikely to attract private-sector capital into biomass farm investments. Yet, while dedicated energy farms may be among the costlier components of a refinery's feedstock supply portfolio, they are indispensable in that they alone reduce supply and pricing uncertainties associated with other cellulosic feedstock sources such as forestry and agricultural residuals.

Fuels Conversion-Much of the AHB conversion work is based on Zeachem's biochemical process that begins with biomass fractionation and the recovery of the hemicellulose and cellulose components. Carbohydrates are enzymatically hydrolyzed with the resulting five- and six-carbon sugars fermented to acetic acid by acetogenic microbes (e.g., Moorella thermoacetica.) The acetic acid undergoes esterification to produce acetate ester. The acetate ester is then hydrogenated to ethanol. An alternative fermentation path to propionic acid and propanol has also been developed. The process is well suited for hybrid poplar, because of the feedstock's relative ease of fractionation and its high acetyl and xylose contents. An advantage of the acetogenic pathway is its excellent carbon yields which result in a large absolute reduction in global warming potential on a unit land basis. The University of Washington has shown that the process leads to a global warming potential that is $66 \%$ lower than that of petroleum-based jet fuel depending on the specific process design and operating conditions. Both ethanol and propanol can be treated to make hydrocarbon fuels; the University of Washington has demonstrated the efficiency of dehydration in converting ethanol to ethylene with high yields. A nickel oligomerization catalyst has been developed to produce olefins, paraffins, and napthenes from ethylene [27]. The hydrogen required for the hydrocarbon fuels can be produced from residual lignin or natural gas with the natural gas reforming approach being technically efficient.

Environmental and Economic Sustainability-The University of California, Davis evaluated the economic sustainability of producing fuels and chemicals from poplar using a series of integrated models covering the entire production system [28]. Initially, biomass yields are projected for each region's climatic and edaphic condition using a modified 3PG (Physiological Principles in Predicting Growth) growth model tailored to hybrid poplar coppice production [29]. Land that could produce more income from poplar than that of the current crop(s) is then identified with an improved agricultural economic model. Generally, these are marginal croplands or pastureland. Optimum biorefinery locations and capacities are next modeled using the Geospatial Bioenergy Systems Model (GBSM) [30] based on feedstock and fuel conversion costs. The IMPLAN model at that point evaluates the economic and social impact of biorefinery operation. Finally, a hybrid poplar submodule, developed in the Environmental Policy Integrated Climate (EPIC) model, simulates soil biogeochemical processes and soil and water quality impacts from poplar biomass cultivation. All modeled outputs are then combined to quantify the available land and production capacity across the four AHB regions. In aggregate, there are approximately 6.54 and 32.46 million respective hectares of croplands and rangelands in the region, of which $6.03(92.2 \%)$ and $12.86(39.6 \%)$ million hectares are potentially suitable for poplar cultivation under the right economic and market conditions. Thus, AHB has concluded that there is an adequate 
land base to support a poplar biofuels industry. For instance, marginal lands without irrigation alone could annually supply 120 tera grams of feedstock for conversion into approximately 39,730 million liters (l) of aviation fuel assuming a conversion rate of $330 \mathrm{l} \mathrm{Mg}^{-1}$ [31]. The focus on marginal lands is rooted in a potentially large base assuming the breeding of adaptable crop varieties [32]. Weaknesses involve economic viability and the uncertainty of environmental impacts and benefits. The significant influence of land costs within bioenergy financial models drives the need for less expensive but lower quality land, the tradeoff between soil quality and yield notwithstanding [21].

\section{Breakout Sessions}

The summit's three breakout sessions were organized around AHB's work on feedstock production, fuels conversion, and markets and policy and reflect the organization the Northwest Advanced Renewables Alliance (NARA) 2017 USDA CAP survey (Feedstock, Processing, Economics, Sustainability) [33]. The AHB summit breakout sessions also closely paralleled the alcohol-to-jet fuel development goals of the Federal Alternative Jet Fuels Research and Development Strategy [1]. The objective of the sessions was to pinpoint, from an investor's perspective, drivers and barriers to commercializing biomass farms and biorefineries. Drivers uncovered in the NARA 2017 USDA CAP survey were: (1) government policy, (2) co-products, (3) reduction in carbon emissions, (4) volatility in oil pricing, (5) energy independence and security, and (6) rural economic development [33]. Barriers were: (1) High production cost (mostly associated with feedstock costs); (2) policy uncertainty; (3) competition with petroleum fuels; (4) capital availability; (5) technological availability; (6) cellulosic biofuels logistics; and (7) consistency of feedstock supply. These coincide remarkably well with the recommended priorities stemming from the second pertinent study, the Canadian Forest Service two-round Delphi survey [34]. These are listed in descending order of importance: (1) Develop the demand for short-rotation, intensive-culture (SRIC) biomass and services; (2) establish policies and programs promoting renewable fuels, bioproducts, and environmental services; (3) establish policies and programs promoting the application of SRIC; (4) establish policies and programs to reduce greenhouse gas emissions; (5) develop production technologies for SRIC; (6) develop conversion technologies for woody biomass.

Feedstock Production-The panelist identified three priorities in improving returns from investments into growing and delivering biomass feedstock. First is improvement in breeding and selection to increase poplar per-hectare biomass yields by $20 \%$ in the near term through conventional breeding techniques; long-term potential is to double the biomass yields using molecular breeding tools to eliminate physiological constraints to biomass productivity [35]. Breeding for water use efficiency, was strongly recommended in the session as an essential imperative to the cultivation of lower quality and less costly lands that would move production costs to a more competitive position [36] (cultivation of under-utilized or non-productive lands using perennial energy crops is also key to exploiting carbon sequestration markets [37]). It was recognized that genetic modification has made great strides in yield improvement and drought tolerance, but commercialization of transgenic varieties may be problematic insofar as environmental certification agencies are concerned. Either concurrently or in place of genetic improvement, endophyte technology developed by AHB at the University of Washington and now commercialized by Intrinsyx Technologies was recommended to improve the water-use efficiency in existing commercial hybrid varieties. The panel also recognized variation in saccharification efficiency as an enormous opportunity to reduce the conversion costs through varietal selection using genomic tools. It is a priority of CBI at Oak Ridge National Laboratory to develop such varieties that undergo pre-treatment and hydrolysis with increased cost-effectiveness. Finally, the feedstock panel felt it important to reduce the cost of vegetation management particularly during the first cutting cycle.

Second, the panel recognized that the environmental attributes of poplar production will immeasurably improve the feedstock production economics when effectively monetized. This may resolve the conflict between economic and ecological interests which is identified as one of the key 
limiting factors to the development of the bioenergy industry [18]. Chief among poplar's ecological attributes are water quality enhancement and carbon sequestration. However, three impediments to monetizing such benefits were foreseen by the feedstock panel. First is the perception that ecosystem service values are difficult to leverage, because opportunities are often geographically dispersed and provide general common services such as clean ground water. Nonetheless, publicly owned treatment works that are growing poplar to process municipal effluent are a tangible ecosystem service provider. Moreover, USDA Rural Development and EPA's Clean Water Revolving Fund are potential sources of loan guarantees for poplar farms that utilize wastewater discharge. Second are investors who seldom allow for new and untried markets in their financial models when considering timber or biomass funds. Yet, over 48,000 hectares in the lower Mississippi River valley formally cultivated for soybeans, corn, and cotton, have now been afforested with poplar interplantings resulting in 2.3 million metric tons of sequestered carbon transacted in voluntary markets with credits registered through the American Carbon Registry [38]. Third is that payments for ecosystem values, while covering annual maintenance costs, do not provide much assistance with major capital expenditures. A suggestion was then offered by the panel that a feasibility and marketing study be commissioned to assess the viability of a Pacific Northwest poplar carbon-sequestration cooperative. The advantage of a cooperative is that it would achieve the scale necessary to improve access to carbon markets through the aggregation of many moderate- and small-sized poplar landowners that contribute land and equipment. Finally, it was recommended that an agroforestry initiative (i.e., mixed cropping systems for food and energy) could provide an ancillary supply of feedstock while providing ecosystem services compatible with a variety of environmental goals of participating land owners. The recommendation included the use of the Washington State University AHB extension team for outreach and education to generate greater landowner willingness to grow bioenergy crops [39].

Third, the feedstock panel spoke to the farm-refinery interface as a good prospect to improve feedstock logistics and delivered costs if focused on two main challenges: (1) Lowering the cost of mechanized, single-pass harvest operations and (2) optimizing the timeliness of feedstock delivery in a form that meets piece-size specifications to improve pre-treatment processing. Detailed suggestions were then made: (1) Scheduling the timing of harvest operations to coincide with the availability of local agricultural equipment and operators; (2) separating foliage from summer biomass to allow for year-round harvesting; (3) arranging for a 3:1 ratio of support units-to-harvesters for efficient biomass transfer to farm gate; (4) setting a minimum headland width of $60 \mathrm{~m}$ during field layout to ensure adequate harvester turning radius; and (5) refining a tracked system to allow harvesters to operate on wet ground. Other suggested engineering upgrades in the single-pass harvesting system itself included increasing harvester horsepower to handle the increased size of poplar coppice, improved feeding of trees in to the chipping unit, and decreasing the number of chipper knives on the chopper drum to reduce horsepower demand and fuel consumption. Design changes to improve chip specifications may be most vexing, as varying the speed of the harvester is the only current way to affect chip size. Complications also arise when harvesters are operated at excessive speeds (e.g., speeds greater than $8 \mathrm{~km}$ per hour) as sawing efficiency is lost partially dislodging the root stock and tearing or shattering stools to the point that coppice regeneration is impacted. Alternatively, two comments from the panel addressed the issue improved pre-treatment processing by optimizing piece-size specifications: (1) A three-stage milling pretreatment process has shown to lower the processing costs of forest residuals and may be applicable to poplar [40], and (2) AHB on the other hand has determined that the effectiveness of pre-treating poplar chips with steam explosion now appears to be insensitive to chip size.

Fuels Conversion-The panel accepted the proposition that the recalcitrance of cellulosic biomass is the most significant obstacle to the establishment of a cellulosic biofuels industry [41]. Recommendations to move poplar biofuels to a competitive position from the conversion session were made within three general guiding principles: (1) A reduction in operating costs is an imperative, (2) the capital cost of biorefineries needs to be significantly reduced, and (3) refineries need to demonstrate that they can 
operate continuously with current technology. (AHB research has shown that alternative jet fuel can be produced from poplar at $\$ 0.70 \mathrm{~L}^{-1}$, well above current aviation fuel prices of $\$ 0.48 \mathrm{I}^{-1}$ )

The best way to accomplish all three is to move to a moderate scale production facility for demonstration and empirical testing: one that is small enough not to require more than $\$ 100$ million in capital investment, but large enough to have acceptable economic returns. A modest scale biorefinery, especially a first-generation factory, will require substantial policy support to be economically viable. Concurrently, attention should be focused on how to build scale to improve economics for the long term. This recommendation is based on the panel's experience that moving directly to commercial-scale refinery construction has often involved contractors with the wrong expertise; one panelist spoke of constructing fermentation tanks using vendors who had never made fermenters leading to problems with tank finish and subsequent contamination. Another panelist mentioned that it may be difficult to enlist top contractors to take on the design and construction of small-sized biorefineries when their primary attention is drawn to larger projects in the pulp and paper sector. The panel also recommended that the region's first commercial plant should co-locate with existing industrial complexes that offer affordable infrastructure and cost-sharing. As an example, the TerraPower representative stated that his company's nuclear power generation could provide low-cost, excess process heat under $290^{\circ} \mathrm{C}$ to reduce the cost of power production at a nearby biorefinery. The Pacific Northwest paper industry may be potentially interested in a similar arrangement based on reports of retooling pulping operations to extract acetic acid and hemicellulose from pulping streams under mild conditions for co-product production while maintaining fiber quality and quantity [42,43]. Sulfite pulp mills offer a unique opportunity for co-location as they have a sugar rich waste stream that could be readily fermented to produce fuels and chemicals. A second idea to lower operating cost was to address the dilution factor of products coming from the fermenter that not only affects the refinery operating costs, but also a refinery's energy footprint.

The panel felt a simpler conversion process is warranted, especially one featuring a less-expensive pre-treatment process. Consolidated bioprocessing (CBP)—co-treatment with cellulolytic anaerobes to improve the efficiency of cell wall deconstruction and carbohydrate solubilization-and co-treatment were presented during the opening keynote as one way to simplify the conversion process. The merits of CBP in reducing biorefinery operational steps and chemical inhibitors were discussed as early as 2012 [44]. Questions were raised as to the likelihood that the CBP approach can take woody material to alcohol fuels without pre-treatment and added enzymes. Accordingly, the consensus was for AHB to continue its focus on the current approach promoted by NREL, Zeachem and others, but to support research and development of novel approaches such as CBP.

One innovative approach being pursued at the University of Washington is increasing the amount of sugars recovered during the pre-treatment and enzymatic hydrolysis by biomass pre-processing with neutral or acidic washes. Removal of ash and extractives also exhibits increases in fermentation ethanol yields. This led to a panel discussion about the advantage of poplar and willow in pre-treatment compared with other non-woody perennial feedstocks; grasses have a higher ash content and therefore consume more chemicals during their removal. Residual supplies-both agricultural and forestry-are similarly disadvantaged by soil particles picked up during harvest and baling operations. The panel also discussed thermo-conversion approaches. The panel recognized the potential of these technologies, but advised caution citing commercial failures with pyrolysis and gasification. It was noted, however, that Velocys and others are active in developing gasification/Fischer-Tropsch as an alternative conversion technology. Also mentioned was Shell/CRI continuous catalytic thermo-chemical process $\left(\mathrm{IH}^{2}\right.$ technology) in India, and Ensyn/UOP Rapid Thermal Processing for both refinery co-processing and stand-alone upgrading of pyrolysis oil.

The panel endorsed the production of bio-based chemicals in place of or co-produced with fuels based on AHB conversion economics. This is in line with reports that future biorefineries will encompass multiple process streams to produce transportation fuels, co-products, and direct energy [35]. Production of chemicals enables smaller factories, offers better carbon benefits, and may 
facilitate the targeting of less volatile markets (these markets often utilize petroleum by-products and may be similarly price-challenged in the current environment of low-cost oil). Process streams with good economic potential include those derived from poplar foliage (e.g., natural pesticides) and the xylose-rich liquid stream produced after steam explosion. Valuable fermentation products include alcohols, acids, aldehydes, esters, and various nitrogen- and sulfur-containing compounds used in flavor enhancers, fragrances, and personal care products. Studies were quoted that acetic acid can be produced at a cost of $\$ 300 \mathrm{Mg}^{-1}$, well below the current selling price of about $\$ 500 \mathrm{Mg}^{-1}$ [45]. Organic acids and sugar alcohols were mentioned as having similarly favorable economics. These will require separation of the five- and six-carbon sugars which can be easily done following the pre-treatment. Mention was made of the importance of extracting lignin in its reactive form for manufacturing carbon fibers. The panel noted that the use of a variable raw material such as lignin is challenging, and that commercialization of a reliable process may be some ways off.

Markets and Policy—The panel agreed with prevailing projections that oil prices may vary considerably, but will stay below $\$ 80$ a barrel at least for the next five years, perhaps longer. The panel addressed the wide discrepancy between the price required by biomass and biofuel producers and current market prices. The AHB economic study of the four regional demonstration farms has concluded that it is nearly impossible to find tenable biomass investment opportunities in today's petroleum markets. Only the Oregon and Washington regional studies get close to the AHB $\$ 91 \mathrm{Mg}^{-1}$ benchmark for ethanol production, which is above biorefinery product cost expectations. The high cost of land is problematic in California. And the Idaho study that includes water treatment as an ancillary environmental benefit, may be of limited opportunity in the region.

The magnitude of the market challenge was demonstrated in the session using estimated production costs of $\$ 1.16$ to $\$ 1.43 \mathrm{~L}^{-1}$ for jet fuel made using poplar biomass grown on nonarable land in California, or $\$ 0.95$ to $\$ 1.19 \mathrm{~L}^{-1}$ for biomass grown on irrigated cropland, when the current pricing of petroleum-derived jet fuel is $\$ 0.48 \mathrm{~L}^{-1}$ [28]. Consequently, policies assisting both feedstock production and fuels conversion would be inordinately advantageous, along with market strategies to enhance the competitive position of the biofuels industry. The panel felt that developing and monetizing environmental and social benefits beyond energy supply should be part of any market development work. The panel recognized that stable government backing, in terms of regulatory and funding support, will be indispensable to the growth of the industry. To illustrate, the petroleum industry's transformational development of hydraulic fracturing was in a large measure owing to U.S. government funding support [46]. However, some have projected that the biofuels industry will be sustainable without government mandates or supports if crude oil prices remain above $\$ 100$ per barrel [47].

Markets-Co-products were acknowledged as undeniably useful in improving the feedstock economics, while it was recognized that this focus would delay the move to large scale fuel production. Nevertheless, the panel noted that co-products are also very important in petroleum economics where they provide a substantial portion of refinery profits and, therefore, merit comparable and immediate attention in biorefinery market economics. The panel also endorsed monetizing the ecosystem services of poplar biomass cultivation but believe that these will be tricky to quantify. There are opportunities such as wetland credits, carbon markets, nutrient trading, etc., but the respective financial potential is not entirely clear and the analysis complicated. Nonetheless, the panel decided that the incorporation of ecosystem service markets into financing models is a legitimate undertaking, but only if accompanied by detailed definition of existing and future environmental markets. Development of a professional sales program was advised with waste-water treatment, carbon sequestration, and salmon habitat restoration considered the primary markets. A persuasive argument for carbon life cycle analyses and the carbon neutrality or low-carbon ratings of biofuels was also encouraged. The dialogue must be transparent and reliant upon rigorous science.

The panel suggested quantifying the long-term influence of poplar feedstock production on food production and enhancement of rural economies. Quantifying the social benefits of biofuels will 
justify policy interventions that provide the necessary financial support. It was strongly advised that landowners be brought into the discussion. Again, it was directed to initiate a strong public education and government affairs campaign but proceeding cautiously so as not to oversell the benefits of biofuels.

Policy-Today, biofuels are where the renewable solar and wind industries were 20 years ago in their move to commercialization. The commercialization of those two industries was assisted by legislative initiatives including production tax credits, renewable energy standards, low carbon fuel standards, renewable portfolio standards, etc. The panel suggested that campaigns to bring parity to biofuels (e.g., subsidies, research funding, new market tax credits for rural development and economically depressed areas, renewable portfolio standards, low carbon fuel standards, and purchase power agreements) should start at the grass roots level following the examples of the wind and solar sectors. There are two arguments for ongoing subsidy. One is to balance the subsidized support received by the petroleum industry at least in the form of percentage depletion of development costs for tax purposes, and possibly others. The second argument is to counter the environmental externalities associated with use of fossil fuels. Carbon credits accomplish this by recognizing: (1) The offset in emitted carbon when the fuel is burned by the growth of the biofuels and (2) the carbon fixed in the soil by the production of the feedstock when marginal agricultural lands are converted to biomass plantations. The panel also suggested that a strong case can be made for subsidized research and development in view of the attractive social and environmental benefits associated with poplar biomass cropping. Once it is determined how much funding is needed, discussions with State and local governments should begin to gain support for regional job creation, economic development, brownfield re-vitalization, and environmental services (the panel felt that political support at the federal level is uncertain, and better opportunities exist at the regional level). However, the question was raised whether regional policies will be sufficiently stable to attract private investment. For instance, the State of Washington's policy for government purchase of renewable diesel fuel was intended to stimulate private sector investments, but fleet policies have not led to the growth of public markets. It was recognized that policy initiatives may make financing more difficult, but investment mechanisms are developing for the environmental and sustainability value that investors are keen to incorporate into their portfolios. Regardless of the level at which policy initiatives take place, success will be contingent on demonstration of real energy gains, greenhouse gas reductions, food security, and preservation of biodiversity [37]. The panel strongly recommended that any new policy initiatives be technology neutral.

It was also suggested that AHB take a closer look at the policy support mechanisms that are already in place or pending. These include: (1) RFS \& D5/D3 RINS which support cellulosic fuels, (2) California tax credits for diesel sold into the State's market rack price, (3) Federal tax policy, (4) California Low Carbon Fuel Standards, and (5) Carbon Offsetting and Reduction Scheme for International Aviation (CORSIA) to be in place beginning in 2020. Finally, the panel's opinion was that the summit's effort to effect market and policy changes must take into account the petroleum industry's significant market power and uncertain reception to change. It may therefore be difficult to advance policies with a long-term perspective. To counter this influence, the panel recommended the summit work with the agriculture industry in devising policy proposals that draw strength from the diversity of energy feedstocks (i.e., starch vs. cellulosics, residuals vs. dedicated, herbaceous vs. woody materials). The panel also recommended reaching out to the electrical utility sector that should be receptive to renewable energy in view of the current trend of electrification of the nation's transportation fleet.

\section{Recommendations}

The AHB project was intended to reduce the risk of progressing hybrid poplar biofuels production from research and demonstration to commercialization. Despite stiff competition in today's aviation fuels market, opportunities for a renewable fuels industry will very likely materialize as some analysts casts doubts on the future of the major international oil companies, stating that their, " . . business model 
rooted in assumptions of ever-growing oil demand, oil scarcity and the need to increase bookable reserves, ... increasingly lacks validity" [48]. The increase in the use of energy from renewable sources is supported by falling technology costs and by fluctuation in fossil fuel prices [49]. Building on five years of AHB effort, the bioenergy summit debated the risks and barriers to commercialization of the hybrid poplar biofuels experience. The summit's findings generally support the 2014 GAO Report that the foremost-perhaps the only-impediment to achieving a workable poplar alternative jet fuels market is making the price competitive with conventional jet fuels [2]. Uncertainty in the policy and the regulatory arena is likewise critical, but the cost of conventional jet fuel is the only real obstacle to the alternative jet fuels industry. While the aviation industry is keen for a reliable and sustainable supply of biofuels that is environmentally well-graded, the summit representative from the aviation industry made clear that the airlines can only bear a small amount of incremental costs for biofuels and that only at the outset of the industry. With this market reality in mind and the goal of moving hybrid poplar biofuels from demonstration to commercialization, the following 11 key findings and recommendations were drawn from the breakout and plenary sessions.

1. Bioproducts focus-Initially, a strategic plan should be put together around markets for bioproducts (alcohol sugars, nanocellulose, lignin carbon fiber, etc.,). It should evaluate and select markets based on their ease-of-entry, competitive advantage over petroleum or conventional sugar platforms, and operating margins. Caution is urged for opportunities that require new technologies and processes or involve unproven bioproducts. The plan should consider this a near-term commercialization approach.

2. Biofuels focus-The plan should further include a path to biofuels commercialization that meets USDA's priorities to create jobs and economic opportunity for regional rural communities, while enhancing existing agricultural and forestry industries, create ecosystem services, and help meet the global demand for alternative aviation fuel. This component should take the form of a blueprint for successive projects to build out the industry, and must address the principal cost drivers of biomass, energy, and enzymes. Initial conversion processes need to utilize available, inexpensive, and proven technology that is straightforward in design and modest in complexity. Pre-treatment especially needs to be simple and capable of reasonable product yields; assumptions around the rate of fuels conversion must be conservative. Pre-treatment designs that specify low energy requirements are particularly desirable owing to significant cost savings. Minimizing technological risks should be similarly emphasized.

3. Project financing-The summit viewed public-private financing mechanism as a likely prerequisite to the initiation of the industry. Concern was voiced, however, that differences between the public and private sectors in deal-making velocity, risk tolerance, and bureaucracy will be difficult to bridge.

4. Ecosystem services-The summit endorsed an analysis of opportunities for revenue streams involved in marketing water quality and carbon sequestration credits.

5. Production scale-The strategic plan should quantify the smallest possible plant size that achieves a target return on investment for manufacturing selected bioproduct(s). The size of the biorefinery could be expressed in terms of feedstock flow just as petroleum refineries are rated in barrels of oil per day. The plan should also specify the percentage of feedstock supplied by dedicated poplar farms, the required area of the farms, biomass yields, and bioproduct conversion rates. State bonding capacity should enter the calculus of production scale. To illustrate, The State of Oregon approved $\$ 245$ million in bonds for Red Rock Biofuels' Lake County refinery to produce up to 60 million liters of aviation biofuel annually from 159,000 Mg of forestry waste via the Fischer-Tropsch conversion process [50].

6. Plant location-The siting of the first plant is critical. Co-location with existing industrial complexes that offer affordable infrastructure, cost-sharing, and utilities is recommended as the economics for a stand-alone plant are universally recognized as difficult. Integration with existing 
industrial plants can lower waste treatment, boiler and turbine expenses that may account for half of the capital costs. Co-location is exceptionally valuable where access to transportation hubs are found. Furthermore, the level of community support needs to be a part of the siting assessment; the summit recognized the importance of rural communities in commercialization. The use of spatial resource models can optimize the allocation of area to individual feedstock species or varieties for supplying distributed demand centers [51].

7. Required feedstock pricing-An important component of securing investment into dedicated energy farms is quantifying the influence that volatility in open-market fuel pricing has on pricing for farm-grown feedstock. AHB has previously modeled the cost of biomass required to achieve a breakeven position for a given ethanol selling price. This should be broadened to include incremental revenue from ecosystem services that, while helpful, is insufficient itself to put the bio-refinery system on par with petroleum. Minimum ethanol selling price for product produced in Brazil from plantation eucalyptus feedstock when marketed in North America is less $\left(\$ 0.74 \mathrm{~L}^{-1}\right)$ than domestic ethanol produced from coppice poplar and willow ( $\$ 0.83$ to $\$ 1.02 \mathrm{~L}^{-1}$ ) [52].

8. Varietal adaptability-The first paper published in the journal "Biomass and Bioenergy" posed the question whether the large yield gains achieved in agricultural crops would be duplicated in the poplar biomass industry [53]. Accordingly, the summit asked for a detailed timeline and cost of developing new energy varieties when focused on adaptation to sites of marginal agricultural quality by traditional breeding or transgenic approaches. Marginal sites in the AHB region are defined as droughty and shallow soils. Work in varietal adaptability should address research mechanisms, participating organizations, and base genetic resources involved. Basic investigations into cellulose and hemicelluloses synthesis and cell wall integration should be integrated into applied poplar breeding programs to ensure that such efforts account for improved biomass chemistry that undergoes cost-effective hydrolysis [41]. The payoff in terms of yields and lower land costs will greatly affect the estimates of investment returns.

9. Efficient bioprocessing-Processes that can result in more efficient conversion and lower processing costs—such as CBP—should be developed further. Those processes that look most promising need to be operated at the pilot and demonstration scales to generate the data and operational experience necessary for commercialization.

10. Regulations-Critical legislative and regulatory issues need to be enumerated considering the investor requirements and the public perception of the environmental value of biofuels. Strategic planning should prioritize potential policy initiatives at both the federal and regional levels.

11. Environmental effects-Current investigations substantiate that poplar bioenergy crop cultivation enhances ecosystem services and likely boosts biodiversity while maintaining crop yields [54]. These should be extended to the highly complex relationships that exists in managing a multifunctional landscape. A priority will be quantifying the value of bioenergy cropping on ecosystem services beyond that of greenhouse gas emissions [55].

\section{Summary}

Initial commercialization for a biofuels industry in the Pacific Northwest and northern California should be developed working with both the public and private sectors. The commercial venture should begin at a small- to modest-scale that minimizes the capital investment and operating costs. A private-public financing model that has a lower return expectation than a private investment model should be pursued. Development should target rural areas and small municipalities in proximity to residual forest-biomass supplies and with the necessary infrastructure into which a hybrid poplar plantation operation can be integrated [56]. Co-products and ecosystem service markets are essential, as are: (1) Research needs to surmount future technical issues; (2) refinery opportunities for co-location with existing industries; (3) support of regional legislators and policy makers; and (4) public-private 
financing mechanisms. The importance of varietal improvement through traditional and molecular breeding methods is stressed.

Author Contributions: Project administration, R.R.G., Feedstock Production Team lead, B.J.S.

Funding: This research was funded by the United States Department of Agriculture, National Institute for Food and Agriculture, Grant no. 2011-68005-30407, Agriculture and Food Research Initiative.

Acknowledgments: The authors gratefully acknowledge the support of the United States Department of Agriculture National Institute of Food and Agriculture (USDA-NIFA).

Conflicts of Interest: The authors declare no conflict of interest.

\section{References}

1. Aeronautics Science and Technology Subcommittee Committee on Technology. Federal Alternative Jet Fuels Research and Development Strategy; Executive Office of the President of the United States, National Science and Technology Council: Washington, DC, USA, 2016; 32p.

2. General Accountability Office. Alternative Jet Fuels: Federal Activities Support Development and Usage, but Long-Term Commercial Viability Hinges on Market Factors; Report to Congressional Requesters; Government Accountability Office: Washington, DC, USA, 2014.

3. Herrera, S. Bonkers about biofuels. Nat. Biotechnol. 2006, 24, 755-760. [CrossRef] [PubMed]

4. Lynd, L.R. The grand challenge of cellulosic biofuels. Nat. Biotechnol. 2017, 35, 912-915. [CrossRef] [PubMed]

5. Lynd, L.R.; Laser, M.S.; Bransby, D.; Dale, B.E.; Davison, B.; Hamilton, R.; Himmel, M.; Keller, M.; McMillan, J.D.; Sheehan, J.; et al. How biotech can transform biofuels. Nat. Biotechnol. 2008, 26, 169-172. [CrossRef]

6. What happened to biofuels? Econ. Technol. Quart. Available online: https:/www.economist.com/technologyquarterly/2013/09/05/what-happened-to-biofuels (accessed on 5 August 2019).

7. Fitzgibbon, T.; Janssens, T. Profitability in a Word of Overcapacity. McKinsey and Company 2015 Report. Available online: https://www.mckinsey.com/industries/oil-and-gas/our-insights/profitability-in-a-world-ofovercapacity (accessed on 19 February 2018).

8. A future of cheap oil. The Week Magazine. Available online: https://theweek.com/articles/717582/futurecheap-oil (accessed on 5 August 2019).

9. Schnoor, J.L. Cellulosic biofuels disappoint. Environ. Sci. Technol. 2011, 45, 7099. [CrossRef] [PubMed]

10. Crawford, J.; Shan, C.; Budsberg, E.; Morgan, H.; Bura, R.; Gustafson, R. Hydrocarbon bio-jet fuel from bioconversion of poplar biomass: Techno-economic assessment. Biotechnol. Biofuels 2016, 9, 141. [CrossRef]

11. Gonzalez-Garcia, S.; Gasol, C.M.; Gabarrell, X.; Rieradevall, J.; Moreira, M.T.; Feijoo, G. Environmental profile of ethanol from poplar biomass as transport fuel in Southern Europe. Renew. Energy 2010, 35, 1014-1023. [CrossRef]

12. Budsberg, E.; Crawford, J.; Gustafson, R.; Bura, R.; Puettmann, M. Ethanologens vs. acetogens: Environmental impacts of two ethanol fermentation pathways. Biomass Bioenergy 2015, 83, 23-31. [CrossRef]

13. Regalbuto, J. Cellulosic biofuels: Got gasoline? Science 2009, 325, 822-824. [CrossRef]

14. Schill, S.R.S.; Bailey, A. Inside the cellulosic industry. Ethanol Prod. Mag. 2017, 23, $20-25$.

15. Adler, P.R.; Del Grosso, S.J.; Parton, W.J. Life-cycle assessment of net greenhouse-gas flux for bioenergy cropping systems. Ecol. Appl. 2007, 17, 675-691. [CrossRef]

16. Camargo, G.G.T.; Ryan, M.R.; Richard, T.L. Energy use and greenhouse gas emissions from crop production using the farm energy analysis tool. Bioscience 2013, 63, 263-273. [CrossRef]

17. González-García, S.; Bacenetti, J.; Murphy, R.J.; Fiala, M. Present and future environmental impact of poplar cultivation in the Po Valley (Italy) under different crop management systems. J. Clean. Prod. 2012, 26, 56-66. [CrossRef]

18. Cook, J.; Beyea, J. Bioenergy in the United States: Progress and possibilities. Biomass Bioenergy 2000, 18, 441-455. [CrossRef]

19. Gelfand, I.; Sahajpal, R.; Zhang, X.; Izaurralde, R.C.; Gross, K.L.; Robertson, G.P. Sustainable bioenergy production from marginal lands in the US Midwest. Nature 2013, 493, 514-517. [CrossRef] [PubMed]

20. Updegraff, K.; Baughman, M.J.; Taff, S.J. Environmental benefits of cropland conversion to hybrid poplar: Economic and policy considerations. Biomass Bioenergy 2004, 27, 411-428. [CrossRef] 
21. Strauss, C.H.; Wright, L.L. Woody biomass production costs in the united states: An economic summary of commercial Populus plantation systems. Sol. Energy 1990, 45, 105-110. [CrossRef]

22. Huang, H.-J.; Ramaswamy, S.; Al-Dajani, W.; Tschirner, U.; Cairncross, R.A. Effect of biomass species and plant size on cellulosic ethanol: A comparative process and economic analysis. Biomass Bioenergy 2009, 33, 234-246. [CrossRef]

23. San Miguel, G.; Corona, B.; Ruiz, D.; Landholm, D.; Laina, R.; Tolosana, E.; Sixto, H.; Canellas, I. Environmental, energy and economic analysis of a biomass supply chain based on a poplar short rotation coppice in Spain. J. Clean. Prod. 2015, 94, 93-101. [CrossRef]

24. Richard, T.L. Challenges in scaling up the biofuels infrastructure. Science 2010, 329, 793-796. [CrossRef]

25. Shuren, R.A.; Busby, G.; Stanton, B.J. A hybrid poplar biomass production cost calculator: A decision tool for farmers and investors. Manuscript in preparation. 2019.

26. Chudy, R.P.; Busby, G.M.; Binkley, C.S.; Stanton, B.J. The economics of dedicated hybrid poplar biomass plantations in the western U.S. Biomass Bioenergy 2019, 124, 114-124. [CrossRef]

27. Jan, O.; Resende, F. Oligomerization of Ethylene to Drop-in Fuel Hydrocarbons Using Bifunctional Heterogeneous Catalysts. In Proceedings of the AIChE Annual Meeting, Salt Lake City, UT, USA, 8-13 November 2015; Available online: https://aiche.confex.com/aiche/2015/webprogram/Paper431489.html (accessed on 19 February 2018).

28. Bandaru, V.; Parker, N.; Hart, Q.; Jenner, M.; Yeo, B.; Crawford, J.; Li, Y.; Titman, P.; Rogers, L.; Kaffka, S.; et al. Economic sustainability modeling provides decision support for assessing hybrid poplar-based biofuel development in California. Calif. Agric. 2015, 69, 171-176. [CrossRef]

29. Hart, Q.J.; Titman, P.W.; Bandaru, V.; Jenkins, B.M. Modeling poplar growth as a short rotation woody crop for biofuels in the Pacific Northwest. Biomass Bioenergy 2015, 79, 12-27. [CrossRef]

30. Parker, N.; Titman, P.; Hart, Q.; Nelson, R.; Skog, K.; Schmidt, A.; Gray, E.; Jenkins, B.M. Development of a biorefinery optimized biofuel supply curve for the western United States. Biomass Bioenergy 2010, 34, 1597-1607. [CrossRef]

31. Crawford, J. Techno-Economic Analysis of Hydrocarbon Biofuels from Poplar Biomass. Master's Thesis, University of Washington, Seattle, WA, USA, 2013.

32. Liu, T.T.; McConkey, B.G.; Ma, Z.Y.; Liu, Z.G.; Li, X.; Cheng, L.L. Strengths, Weaknesses, Opportunities and Threats Analysis of Bioenergy Production on Marginal Land. Energy Procedia 2011, 5, 2378-2386. [CrossRef]

33. Chen, M.; Smith, P.M. The U.S. cellulosic biofuels industry: Expert views on commercialization drivers and barriers. Biomass Bioenergy 2017, 102, 52-61. [CrossRef]

34. Masse, S.; Marchand, P.P.; Bernier-Cardou, M. Forecasting the deployment of short-rotation intensive culture of willow or hybrid poplar: Insights from a Delphi study. Can. J. For. Res. 2014, 44, 422-431. [CrossRef]

35. Ragauskas, A.J.; Williams, K.; Davison, B.H.; Britovsek, G.; Cairney, J.; Eckert, C.A.; Frederick, W.J., Jr.; Hallett, J.P. The Path Forward for Biofuels and Biomaterials. Science 2006, 484, 311-318. [CrossRef]

36. Somerville, C.; Youngs, H.; Taylor, C.; Davis, S.C.; Long, S.P. Feedstocks for lignocellulosic biofuels. Science 2010, 329, 790-792. [CrossRef]

37. Tilman, D.; Socolow, R.; Foley, J.A.; Hill, J.; Larson, E.; Lynd, L.; Pacala, S.; Reilly, J.; Searchinger, T.; Somerville, C.; et al. Beneficial biofuels-The food, energy, and environmental trilemma. Science 2009, 325, 270-271. [CrossRef]

38. Greentrees. Available online: https://www.green-trees.com/ (accessed on 5 August 2019).

39. Gowan, C.H.; Kar, S.P.; Townsend, P.A. Landowners' perceptions of and interest in bioenergy crops: Exploring challenges and opportunities for growing poplar for bioenergy. Biomass Bioenergy 2018, 110, 57-62. [CrossRef]

40. Brandt, K.L.; Gao, J.; Wang, J.; Wooley, R.J.; Wolcott, M. Techno-Economic Analysis of Forest Residue Conversion to Sugar Using Three-Stage Milling as Pretreatment. Front. Energy Res. 2018, 6. [CrossRef]

41. Miller, R.; Keller, M. The DOE BioEnergy Science Center-A U.S. Department of Energy Bioenergy Research Center. In Vitro Cell. Dev. Biol.-Plant 2009, 45, 193-198. [CrossRef]

42. Thorp, B. Biorefinery offers industry leaders business model for major change. Pulp Pap. 2005, 79, 35-39.

43. Mc Burney, S.; Millen, J. Fueling the need for change. Pulp Pap. 2008, 82, 43-47.

44. Limayen, A.; Ricke, S.C. Lignocellulosic biomass for bioethanol production: Current perspectives, potential issues and future prospects. Prog. Energy Combust. Sci. 2012, 38, 449-467. [CrossRef]

45. ICIS Inc. Available online: http://www.icis.com/chemicals/acetic-acid/ (accessed on 5 August 2019).

46. EESI. Available online: http://www.eesi.org/policy/renewable-energy (accessed on 5 August 2019). 
47. Tyner, W.E. The US ethanol and biofuels boom: Its origins, current status, and future prospects. Bioscience 2008, 58, 648-653. [CrossRef]

48. Stevens, P.E. International Oil Companies: The Death of the Old Business Model; Chatham House, the Royal Institute of International Affairs: London, UK, 2016; 45p.

49. Rocio, C.; Pleguezuelo, R.; Zuazo, V.H.D.; Bielders, C.; Bocanegra, J.A.J.; PereaTorres, F.; Martinez, J.R.F. Bioenergy farming using woody crops. A review. Agron. Sustain. Dev. 2015, 35, 95-119.

50. Sapp, M. Red Rock Biofuels scores $\$ 245$ million state bond for Oregon plant. Biofuels Dig. 2019. Available online: https://www.biofuelsdigest.com/bdigest/2018/01/09/red-rock-biofuels-scores-245-million-state-bondfor-oregon-plant/ (accessed on 19 February 2018).

51. Bauena, A.W.; Dunnett, A.J.; Richter, G.M.; Dailey, A.G.; Aylott, M.; Casella, E.; Taylor, G. Modelling supply and demand of bioenergy from short rotation coppice and Miscanthus in the UK. Bioresour. Technol. 2010, 101, 8132-8143. [CrossRef]

52. Stephen, J.D.; Mabee, W.E.; Saddler, J.N. Lignocellulosic ethanol production from woody biomass: The impact of facility siting on competitiveness. Energy Policy 2013, 59, 329-340. [CrossRef]

53. Hansen, E.A. Poplar woody biomass yields: A look to the future. Biomass Bioenergy 1991, 1, 1-7. [CrossRef]

54. Manning, P.; Taylor, G.; Hanley, M.E. Bioenergy, food production and biodiversity-An unlikely alliance? GCB Bioenergy 2015, 7, 570-576. [CrossRef]

55. Milner, S.; Holland, R.A.; Lovett, A.; Sunnenberg, G.; Hastings, A.; Smith, P.; Wang, S.; Taylor, G. Potential impacts on ecosystem services of land use transitions to second-generation bioenergy crops in GB. GCB Bioenergy 2016, 8, 317-333. [CrossRef] [PubMed]

56. Yemshanov, D.; McKenney, D. Fast-growing poplar plantations as a bioenergy supply source for Canada. Biomass Bioenergy 2008, 32, 185-197. [CrossRef]

(C) 2019 by the authors. Licensee MDPI, Basel, Switzerland. This article is an open access article distributed under the terms and conditions of the Creative Commons Attribution (CC BY) license (http://creativecommons.org/licenses/by/4.0/). 